Printed ISSN : $2406-7415$

Electronic ISSN : $2655-9919$

DOI: http://dx.doi.org/10.35137/jabk.v8i2.537

Jurnal Akuntansi dan Bisnis Krisnadwipayana Volume 8 No. 2 (Mei - Agustus) 2021

\title{
PENGARUH OPINI AUDIT TAHUN SEBELUMNYA, UKURAN PERUSAHAAN, LIKUIDITAS, PROFITABILITAS, DAN SOLVABILITAS TERHADAP OPINI GOING CONCERN (STUDI EMPIRIS PADA PERUSAHAAN PERTAMBANGAN YANG TERDAFTAR DI BURSA EFEK INDONESIA TAHUN 2014-2018)
}

\author{
Rodiyatan Mardiah ${ }^{1}$ \\ ${ }^{1}$ Fakultas Ekonomi Universitas Krisnadwipayana \\ Jalan Unkris Jatiwaringin Jakarta Timur \\ Email: rodiatanmardiah15@gmail.com \\ Hayuningtyas Pramesti Dewi ${ }^{2}$ \\ ${ }^{2}$ Fakultas Ekonomi Universitas Krisnadwipayana \\ Jalan Unkris Jatiwaringin Jakarta Timur \\ Email: ethniz@gmail.com
}

\begin{abstract}
This study examines the effect of the previous year's audit opinion, company size, liquidity, profitability, and solvency on going-concern audit opinion on mining companies listed on the Indonesia Stock Exchange for the period 2014-2018. Data were tested using logistic regression. The result of this research is that the previous year's audit opinion variable partially affects going-concern audit, while company size, liquidity, profitability and solvency, respectively, partially have no effect on going-concern audit opinion. Then simultaneously, the five independent variables affect the going concern audit opinion.
\end{abstract}

Keywords: previous year's audit opinion, company size, liquidity, profitability, solvency, going-concern audit opinion.

\section{PENDAHULUAN}

Keberlangsungan usaha merupakan salah satu tujuan sebuah perusahaan, dan juga merupakan indikator bahwa sebuah perusahaan berhasil mempertahankan hidupnya dalam persaingan bisnis. Keberlangsungan usaha atau yang biasa disebut going concern juga menjadi penilaian tersendiri bagi investor dalam mempertimbangkan dimana ia akan menanamkan modalnya. Untuk mencari tahu mengenai keberlangsungan usaha sebuah perusahaan investor dapat menggunakan laporan audit, yang mana di dalamnya terdapat opini going concern. Dalam kaitannya dengan perusahaan yang telah go public, permasalahan going concern dapat menyebabkan sebuah perusahaan delisting dari bursa efek. 
Printed ISSN : $2406-7415$

Electronic ISSN : 2655 - 9919

DOI: http://dx.doi.org/10.35137/jabk.v8i2.537

Jurnal Akuntansi dan Bisnis Krisnadwipayana Volume 8 No. 2 (Mei - Agustus) 2021

Seperti yang terjadi pada sebagian besar perusahaan pertambangan di Indonesia yang listing di Bursa Efek Indonesia. Berdasarkan data yang diperoleh dari BEI sejak bulan Oktober 2011 sampai Januari 2020 terdapat 22

perusahaan yang delisting akibat masalah going concern. Berikut ini adalah data jenis perusahaan yang delisting dari BEI selama kurun waktu tersebut akibat masalah going concern.

Gambar 1

Perusahaan yang Delisting Akibat Masalah Going Concern

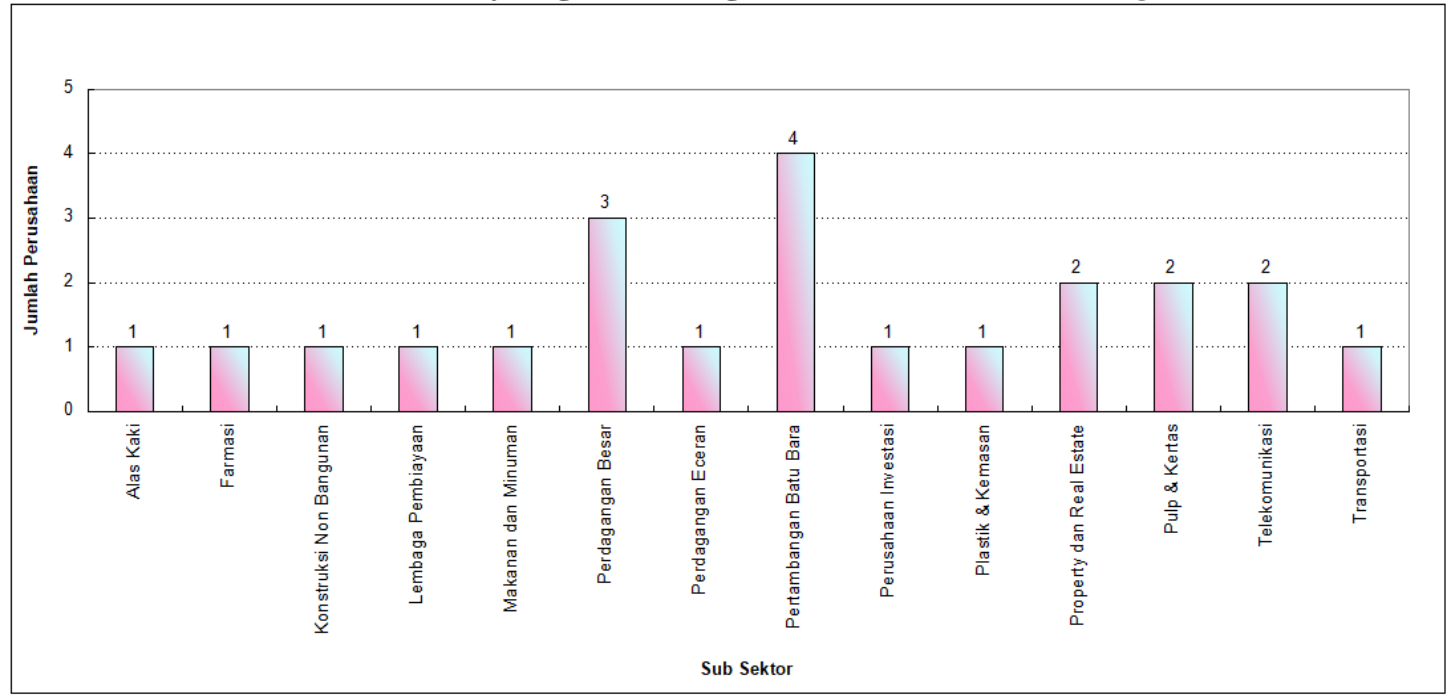

Sumber: BEI, 2020

Sektor pertambangan mengalami pelemahan kinerja akibat terpuruknya harga minyak mentah dan pertumbuhan ekonomi yang menurun di tahun 2015. Hal ini berlangsung sampai tahun 2019 dimana Badan Pusat Statistik mencatat kinerja ekspor hasil tambang kuartal pertama turun sebesar $14.08 \%$ dibandingkan periode sebelumnya (amp.kontan.co.id). Hal ini menyebabkan penurunan laba dan pendapatan, hingga mengalami kerugian yang terus menerus sehingga auditor menyatakan keraguan keberlangsungan usaha sebuah perusahaan dalam opininya. Beberapa penelitian tentang keberlangsungan usaha telah dilakukan dengan beberapa variable bebas yang mempengaruhi opini audit going concern, seperti penelitianLie, Wardani, dan Pikir (2016) dengan variable bebas yaitu solvabilitas, profitabilitas, likuiditas dan rasio pasar, hasil penelitian tersebut ketiga variable bebas yaituprofitabilitas, likuiditas dan rasio pasar berpengaruh terhadap opini audit going concern. Sementara itu, solvabilitas tidak 
berpengaruh terhadap opini audit going concern. Sedangkan penelitian yang dilakukan oleh Sudarno Yoga Adi Haryanto (2019) menunjukkan hasil bahwa variabel solvabilitas dan rencana manajemen memiliki pengaruh terhadap penerimaan opini audit going concernsedangkan variabel likuiditas dan profitabilitas tidak memiliki pengaruh terhadap penerimaan opini audit going concern.Dari kedua penelitian tersebut terdapat perbedaan hasil dari rasio solvabilitas dan profitabilitas terhadap opini audit going concern.Penelitian ini menggunakan variable solvabilitas dan profitabilitas untuk kembali mencari pengaruh dua variable tersebut terhadap opini audit going concern dan menambahkan dua variable bebas lain yaitu opini auditgoing concern tahun sebelumnya dan ukuran perusahaan dengan alasan bahwa opini audit going concern tahun sebelumnya berpotensi untuk mendapatkan opini audit going concern kembali. Adapun ukuran perusahaan dijadikan salah satu variabel dengan alasan ukuran perusahaan juga berpotensi mendapatkan audit going concern, misalnya perusahaan yang masih baru dan memiliki asset yang rendah mungkin akan diragukan keberlangsungan usahanya. Hipotesis yang dapat disusun dari uraian diatas adalah sebagai berikut:

$\mathrm{H}_{1}$ : Terdapat pengaruh opini audit tahun sebelumnya terhadap opini audit going concern

$\mathrm{H}_{2}$ : Terdapat pengaruh ukuran perusahaan terhadap opini audit going concern
$\mathrm{H}_{3}$ : Terdapat pengaruh likuiditas terhadap opini going concern

$\mathrm{H}_{4}$ : Terdapat pengaruh profitabilitas terhadap opini going concern

$\mathrm{H}_{5}$ : Terdapat pengaruh solvabilitas terhadap opini going concern

$\mathrm{H}_{6}$ : Terdapat pengaruh opini audit tahun sebelumnya, ukuran perusahaan, likuiditas, profitabilitas, dan solvabilitas secara simultan terhadap opini audit

going concern.

\section{LANDASAN TEORI}

\section{Auditing}

Menurut Agoes (2016), pengertian auditing adalah suatu pemeriksaan yang dilakukan oleh pihak independen secara kritis dan sistematis terhadap laporan keuangan yang telah disusun oleh manajemen dengan tujuan dapat memberikan pendapat mengenai kewajaran laporan keuangan. Adapun pendapat auditing menurut Miller dan Bailley dalam Halim (2015), An audit is a methodical review and objective examination of an item, including the verification of specific information as determined by the auditor or as established by general practice. Generally, the purpose of an audit is to express an opinion on or reach a conclusion about what was audited. 


\section{Opini Audit}

Menurut Agoes (2016), opini audit adalah pendapat yang diberikan oleh akuntan publik terhadap kewajaran penyajian laporan keuangan yang disusun oleh perusahaan. Auditor bertanggung jawab dalam menyatakan pendapat atas laporan keuangan melalui laporan audit. Audit laporan keuangan memiliki peran yang sangat diperlukan dalam ekonomi pasar bebas dan merupakan bagian terpenting dari berbagai assurance service (Boynton et al., 2015). Bukti audit merupakan informasi yang digunakan oleh auditor untuk dapat menarik kesimpulan sebagai dasar pemberian opini auditnya (Tuanakotta, 2015).Macam-macam opini audit juga tercantum dalam Standar Profesional Akuntan Publik PSA 29 SA Seksi 508 Paragraf 10, yaitu Pendapat wajar tanpa pengecualian (Unqualified opinion), Pendapat wajar tanpa pengecualian dengan bahasa penjelasan yang ditambahkan dalam laporan audit bentuk baku (Unqualified opinion with explanatory language), Pendapat wajar dengan pengecualian (Qualified opinion), Pendapat tidak wajar (Adverse opinion), Pernyataan tidak memberikan pendapat (Disclaimer opinion).

\section{Opini Going Concern}

Menurut Harahap (2015) going
concern adalah suatu postulat yang
menganggap bahwa suatu perusahaan akan
terus melaksanakan operasinya sepanjang
penyelesaian proyek, perjanjian, dan

kegian yang sedang berlangsung. Perusahaan dianggap tidak berhenti, ditutup, atau dilikuidasi di masa yang akan datang. Perusahaan dianggap akan hidup untuk jangka waktu yang tidak terbatas. Nugroho dkk (2018) berpendapat bahwa going concernadalah asumsi keberlangsungan usaha suatu perusahaan untuk dapat terus beroperasi dan diharapkan tidak akan terjadi likuidasi dimasa yang akan datang. Opini audit going concern dikeluarkan oleh auditor untuk memastikan apakah perusahaan dapat mempertahankan kelangsungan usahanya (Minerva dkk, 2020). Ketika sebuah perusahaan mengalami kesulitan keuangan, perusahaan akan menjual sebagian dari asetnya, melakukan merger dengan perusahaan lain, mengurangi pengeluaran modal, negosiasi dengan bank dan kreditur, mengubah utang menjadi saham atau mengajukan kebangkrutan atas ketidakmampuan perusahaan dalam melanjutkan kelangsungan usahanya (Sudana, 2015).

Adapun beberapa faktor yang dapat mempengaruhi opini audit going concern yaitu adalah:

1. Pernyataan audit tahun sebelumnya. Berdasarkan pernyataan dalam SA Seksi 341, penerimaan opini audit goingconcern pada tahun sebelumnya menjadi salah satu faktor auditor dalam mengeluarkan opini audit going concern pada tahun berjalan. Untuk mengetahui apakah ada kesangsian pada kelangsungan hidup perusahaan, maka auditor perlu melakukan 
evaluasi dengan melihat informasi dari rencana manajemen dalam memperbaiki kondisi perusahaan.Dari hasil evaluasi, auditor dapat mengambil kesimpulan apakah masih terdapat kesangsian atas kemampuan dalam mempertahankan kelangsungan usahanya pada perusahaan yang bersangkutan.

2. Ukuran Perusahaan. Auditor meyakini bahwa perusahaan kecil lebih sulit melanjutkan kelangsungan hidup usahanya karena kondisi keuangan perusahaan yang tidak stabil. Perusahaan besar memiliki manajemen yang lebih baik dalam mengelola perusahaan dan menghadapi kesulitan keuangan.Berdasarkan UndangUndang Nomor 20 Tahun 2008 dalam BAB IV pasal 6, terdapat kriteria usaha yang dijadikan sebagai acuan dalam menentukan ukuran perusahaan, yaitu sebagai berikut:

Tabel 1

Kriteria Ukuran Perusahaan

\begin{tabular}{|l|l|l|}
\hline \multirow{2}{*}{$\begin{array}{c}\text { Ukuran } \\
\text { Perusahaan }\end{array}$} & \multicolumn{3}{|c|}{ Kriteria } \\
\cline { 2 - 4 } Usaha Mikro & \multicolumn{3}{|c|}{ Paling banyak 50 Juta } & Paling banyak 300 Juta \\
\hline Usaha Kecil & $\begin{array}{l}\text { Lebih dari 50 Juta } \\
\text { sampai dengan paling } \\
\text { banyak 500 Juta }\end{array}$ & $\begin{array}{l}\text { Lebih dari 300 Juta } \\
\text { sampai dengan paling } \\
\text { banyak 2,5 Miliar }\end{array}$ \\
\hline $\begin{array}{l}\text { Usaha } \\
\text { Menengah }\end{array}$ & $\begin{array}{l}\text { Lebih dari 500 Juta } \\
\text { sampai dengan paling } \\
\text { banyak 10 Miliar }\end{array}$ & $\begin{array}{l}\text { Lebih dari 2,5 Miliar } \\
\text { sampai dengan paling } \\
\text { banyak 50 Miliar }\end{array}$ \\
\hline Usaha Besar & Lebih dari 10 Miliar & Lebih dari 50 Miliar \\
\hline
\end{tabular}

Sumber: Undang-Undang Nomor 20, 2008

Sedangkan menurut Hartono (2017) ukuran perusahaan merupakan suatu skala yang dapat diklasifikasikan dari besar kecilnya perusahaan melalui total aset, $\log$ size, nilai pasar saham, dan lain-lain. Ukuran perusahaan menggambarkan besar kecilnya suatu perusahaan yang dapat dinyatakan dengan total asset, total ekuitas, total penjualan dan nilai pasar saham (Keown 2018).Pada penelitian ini, Ln total asset digunakan sebagai proksi terhadap variabel ukuran perusahaan dengan pertimbangan bahwa nilai aset relatif lebih stabil dibandingkan dengan ekuitas, penjualan, maupun nilai pasar saham. Krissindiastuti dan Rasmini (2016) menyatakan bahwa perusahaan kecil dengan total aset yang rendah memiliki potensi memperoleh opini audit going concern dengan rumusan sebagai berikut: 
Printed ISSN : $2406-7415$

Electronic ISSN : 2655 - 9919

DOI: http://dx.doi.org/10.35137/jabk.v8i2.537

Jurnal Akuntansi dan Bisnis Krisnadwipayana Volume 8 No. 2 (Mei - Agustus) 2021

\section{SIZE $=$ Ln Total Asset}

3. Likuiditas. Likuiditas merupakan rasio yang digunakan untuk mengukur kemampuan perusahaan dalam memenuhi kewajiban jangka pendeknya (Sugiono \& Untung 2016). Menurut Hery (2017), likuiditas adalah rasio yang menunjukkan kemampuan perusahaan dalam membayar utang jangka pendeknya. Sedangkan menurut Kasmir (2017), likuiditas merupakan rasio yang menggambarkan kemampuan perusahaan dalam memenuhi kewajiban jangka pendek.Laporan keuangan merupakan cerminan hasil kinerja manajemen perusahaan. Jika hasil evaluasi yang dilakukan oleh auditor menunjukkan rendahnya kinerja manajemen terhadap likuiditas, maka terdapat potensi perusahaan memperoleh opini audit going concern.Perusahaan yang memiliki tingkat likuiditas tinggi, dapat dinyatakan bahwa perusahaan memiliki kemampuan yang tinggi dalam memenuhi kewajiban jangka pendeknya tepat waktu (Anita 2017). Sebaliknya, jika perusahaan memiliki likuiditas yang rendah menunjukkan bahwa semakin rendah kemampuan perusahaan dalam memenuhi kewajiban jangka pendeknya, sehingga menyebabkan kesangsian bagi auditor atas kelangsungan hidup perusahaan (Nugroho et al., 2018). Kasmir (2017) mengemukakan tiga jenis rasio likuiditas, yaitu Rasio Lancar (Current Ratio), Rasio Cepat (Quick Ratio), Rasio Kas (Cash Ratio). Dari ketiga rasio di atas, indikator yang digunakan dalam penelitian ini adalah rasio lancar. Rasio lancar merupakan rasio paling umum yang digunakan untuk mengetahui kesanggupan perusahaan dalam memenuhi kewajiban jangka pendek dengan menggunakan aset lancar.

Rumus yang digunakan untuk Rasio Lancar adalah sebagai berikut:

$$
\text { Rasio Lancar }=\frac{\text { Aset Lancar }}{\text { Kewajiban Lancar }} \times 100 \%
$$

ProfitabilitasMenurut Kasmir (2017), profitabilitas adalah rasio yang menunjukkan kemampuan perusahaan dalam mencari keuntungan. Perusahaan dengan nilai profitabilitas yang rendah, menunjukkan bahwa perusahaan memiliki kemampuan yang rendah untuk menghasilkan laba yang mengakibatkan keraguan auditor untuk memberikan opini audit going concern. Terdapat empat jenis rasio profitabilitas (Kasmir, 2017), yaitu Net Profit Margin (NPM), Return On Assets (ROA), Return On Equity (ROE), Return On Investment (ROI). Indikator yang digunakan dalam metode pengukuran profitabilitas adalah return on assets. Return On Assets (ROA) menunjukkan

Copyright (c) 2021 Hayuningtyas Pramesti Dewi, SE., Ak., M.Ak., CA., Rodiyatan Mardiyah. 
Printed ISSN : $2406-7415$

Electronic ISSN : 2655 - 9919

DOI: http://dx.doi.org/10.35137/jabk.v8i2.537

Jurnal Akuntansi dan Bisnis Krisnadwipayana Volume 8 No. 2 (Mei - Agustus) 2021

kemampuan dalam menghasilkan laba dari aset yang dipergunakan serta menggambarkan potensi keuntungan

perusahaan sehingga dapat memberikan informasi mengenai kinerja perusahaan. Rumus yang digunakan adalah sebagai berikut:

$$
\text { Return On Assets }=\frac{\text { Laba Bersih }}{\text { Total Aset }} \times 100 \%
$$

4. Solvabilitasmenurut Kasmir (2017) Solvabilitas digunakan untuk mengukur kemampuan perusahaan dalam memenuhi seluruh kewajibannya baik kewajiban jangka pendek maupun kewajiban jangka panjang apabila perusahaan dilikuidasi. Sugiono dan Untung (2016) berpendapat bahwa rasio solvabilitas adalah rasio yang digunakan untuk mengukur perbandingan pembelanjaan menggunakan utang dengan modal dan kemampuan dalam membayar bunga dan beban tetap lainnya. Perusahaan yang memiliki tingkat solvabilitas rendah, dapat dinyatakan bahwa perusahaan memiliki kemampuan dalam melakukan hal pembayaran utang dan bunga sehingga tidak terdapat keraguan auditor dalam kelangsungan hidup perusahaan. Sebaliknya, jika perusahaan memiliki solvabilitas yang tinggi menunjukkan bahwa semakin rendah kemampuan perusahaan dalam hal pembayaran utang dan bunga. Perusahaan dengan utang yang tinggi memiliki kecenderungan bahwa perusahaan mengalami kesulitan keuangan yang dapat menimbulkan keraguan auditor atas kelangsungan hidup perusahaan (Lie et al. 2016).Terdapat beberapa jenis rasio solvabilitas yang sering digunakan perusahaan. Berikut adalah jenis rasio solvabilitas menurut Kasmir (2017) yaitu Debt To Total Assets Ratio, Debt To Equity Ratio, Long Term Debt To Equity Ratio, Times Interest Earned, Fixed Charge Coverage.Dari beberapa jenis rasio tersebut indikator yang digunakan dalam penelitian ini adalah debt to total assets ratioyang merupakan gambaran dari kekayaan perusahaan dibiayai oleh utang. Jika nilai debt to total assets ratiokecil, maka perusahaan dianggap memiliki kinerja keuangan yang baik.

Rumus yang digunakan adalah sebagai berikut:

\begin{tabular}{|ll|}
\hline Debt to Total $\quad$ Total Utang & $\mathrm{x} 100 \%$ \\
\hline
\end{tabular}


Printed ISSN : $2406-7415$

Electronic ISSN : 2655 - 9919

DOI: http://dx.doi.org/10.35137/jabk.v8i2.537

Jurnal Akuntansi dan Bisnis Krisnadwipayana Volume 8 No. 2 (Mei - Agustus) 2021

\section{Assets Ratio $=$}

Total Aset

\section{METODE PENELITIAN}

Penelitian ini merupakan penelitian kuantitatif. Terdapat 5 variable yang digunakan yaitu 1 variabel terikat $(Y)$ dan 4 variabel bebas $(\mathrm{X})$. Variabel $\mathrm{Y}$ dalam penelitian ini adalah Opini Audit Going ConcernSedangkan variable $\mathrm{X}$ dalam

penelitian ini adalah Opini audit tahun sebelumnya $\left(\mathrm{X}_{1}\right)$, Ukuran perusahaan $\left(\mathrm{X}_{2}\right)$, Likuiditas $\left(\mathrm{X}_{3}\right)$, Profitabilitas $\left(\mathrm{X}_{4}\right)$, dan Solvabilitas $\left(\mathrm{X}_{5}\right)$. Berikut ini adalah operasionalisasi variable

Tabel 2

Operasionalisasi Variabel dan Pengukurannya

\begin{tabular}{|l|l|c|}
\hline \multicolumn{1}{|c|}{ Variabel } & \multicolumn{1}{|c|}{ Indikator } & Skala \\
\hline $\begin{array}{l}\text { Opini Audit } \\
\text { Going Concern }\end{array}$ & $\begin{array}{l}1=\text { Menerima opini audit going concern } \\
\text { = Tidak menerima opini audit } \\
\text { going concern }\end{array}$ & $\begin{array}{c}\text { Nominal } \\
\text { (Dummy) }\end{array}$ \\
\hline $\begin{array}{l}\text { Opini Audit } \\
\text { Tahun } \\
\text { Sebelumnya }\end{array}$ & $\begin{array}{l}1=\text { Menerima opini audit going concern } \\
\text { going concern }\end{array}$ & $\begin{array}{c}\text { Nominal } \\
\text { (Dummy) }\end{array}$ \\
\hline $\begin{array}{l}\text { Ukuran } \\
\text { Perusahaan }\end{array}$ & SIZE=Ln (Total Asset) & Rasio \\
\hline Likuiditas & CR $=\frac{\text { Aset Lancar }}{\text { Kewajiban Lancar }} \times 100 \%$ & Rasio \\
\hline Profitabilitas & ROA $=\frac{\text { Laba Bersih }}{\text { Total Aset }} \times 100 \%$ & Rasio \\
\hline Solvabilitas & DTA $=\frac{\text { Total Utang }}{\text { Total Aset }} \times 100 \%$ & Rasio \\
\hline
\end{tabular}

Populasi dalam penelitian ini perusahaan sector tambang yang listing di Bursa Efek Indonesia selama tahun 20142018 sebanyak 46 perusahaan, sedangkan sampel yang diambil berdasarkan kriteria yang telah ditetapkan adalah sebanyak 17 perusahaan. Alat analisis yang digunakan dalam penelitian ini adalah regresi logistik. Penggunaan regresi logistik disebabkan oleh variable dependen yang bersifat dikotomi (terdapat going concern dan tidak terdapat going concern). Teknik 
analisis dengan regresi logistik tidak lagi memerlukan uji normalitas data pada variableindependenkarena

variableindependen dalam penelitian ini merupakan campuran antara variabel kontinu (metrik) dan variabel kategorial (non-metrik) yang menyebabkan tidak terpenuhinya asumsi multivariatenormaldistribution. Berikut merupakan langkah-langkah pengujian dalam penelitian ini:

\section{Uji Keseluruhan Model (Overall Model Fit)}

Langkah pertama adalah menilai keseluruhan model terhadap data. Hipotesis yang digunakan untuk menilai model fit ini adalah:

$H_{0}$ : Model yang dihipotesiskan fit dengan data

$H_{a}$ : Model yang dihipotesiskan tidak fit dengan data

Dari hipotesis di atas, agar model fit dengan data maka hipotesis nol harus diterima atau hipotesis alternatif harus ditolak. Statistik yang digunakan dalam model ini berdasarkan pada fungsi likelihood (L). Likelihood (L) dari model adalah probabilitas yang menunjukkan bahwa model yang dihipotesiskan menggambarkan data input. Menilai model fit ini dihitung dari nilai -2Loglikelihood pada tabel iteration history. Apabila nilai -2Loglikelihood lebih kecil dari chi-square tabel dan terdapat penurunan nilai antara $2 \log L$ awal dengan $-2 \log L$ pada langkah berikutnya, maka menunjukkan bahwa model regresi lebih baik dan model yang dihipotesiskan fit dengan data (Ghozali, 2018).

\section{Uji Kelayakan Model Regresi (Goodnes of Fit Test)}

Kelayakan model regresi dalam penelitian ini dinilai dengan menggunakan Hosmer and Lemeshow's Goodness of Fit Test, yang merupakan model untuk menguji bahwa tidak adanya perbedaan antara model dengan data sehingga model dapat dikatakan fit (Ghozali, 2018). Adapun hasil dari model ini adalah sebagai berikut:

a. Jika nilai statistik Hosmer and Lemeshow's Goodness of Fit Test sama dengan atau kurang dari 0,05, maka hipotesis nol ditolak yang menunjukkan adanya perbedaan signifikan antara model dengan nilai observasinya sehingga nilai observasinya tidak dapat diprediksi oleh Goodness Fit.

b. Jika nilai statistik Hosmer and Lemeshow's Goodness of Fit Test lebih besar dari 0,05, maka hipotesis nol dapat diterima yang menunjukkan bahwa model mampu memprediksi nilai observasinya.

\section{Koefisien Determinasi (Nagelkarke $R$ Square)}

Cox and Snell's $R$ Square merupakan ukuran yang mencoba meniru ukuran $\mathrm{R}^{2}$ pada multiple regression yang didasarkan pada teknik estimasi likehood dengan nilai maksimum kurang dari 1 (satu), sehingga sulit diinterpretasikan. Nagelkerke's $R$ Square dapat digunakan untuk 
memperoleh koefisien determinasi yang dapat diinterpretasikan seperti nilai $\mathrm{R}^{2}$ pada multiple regression. Nagelkerke's $R$ Square merupakan modifikasi dari koefisienCox and Snell untuk memastikan bahwa nilainya bervariasi dari 0 (nol) hingga 1 (satu) yang dapat dilakukan dengan membagi nilai Cox and Snell's $R$ Square pada nilai maksimumnya (Ghozali, 2018). Jika nilai Nagelkarke $R$ Square yang diperoleh kecil, maka kemampuan variableindependendalam menjelaskan variable dependen amat terbatas. Sedangkan apabila nilai Nagelkarke $R$ Square yang diperoleh mendekati satu, maka variableindependendapat memberikan hampir semua informasi yang dibutuhkan agar dapat memprediksi variasi variable dependen (Ghozali 2018).

\section{Tabel Klasifikasi}

Tabel klasifikasi menunjukkan kekuatan prediksi dari model regresi untuk memprediksi probabilitas terjadinya variable dependenyang dinyatakan dalam bentuk persen. Tabel klasifikasi digunakan untuk menghitung nilai estimasi yang benar (correct) dan salah (incorrect). Pada model yang sempurna, maka semua kasus akan berada pada tingkat peramalan 100\% (Ghozali 2018).

\section{Uji Hipotesis}

1. Uji Parsial (Uji Wald)

Pengujian pengaruh secara parsial dapat dilihat pada tabel variabel in the equation dengan uji signifikansi menggunakan statistik wald berdistribusi chi kuadrat. Pengujian dengan model regresi logisitik ini digunakan untuk mengetahui pengaruh dari masing-masing variableindependenterhadap variable dependendengan tingkat kepercayaan yang digunakan adalah $95 \%$ atau taraf signifikansi 5\% $(\alpha=0,05)$. (Ghozali 2018). Kriteria pengujian yang digunakan dalam penelitian ini adalah sebagai berikut:

a. Jika probabilitas signifikansi > 0,05, maka hipotesis nol diterima yang berarti terdapat pengaruh signifikan antara variableindependensecara parsial terhadap variable dependen.

b. Jika probabilitas signifikansi $<0,05$, maka hipotesis nol ditolak yang berarti tidak terdapat pengaruh signifikan antara variableindependensecara parsial terhadap variable dependen.

Adapun persamaan model regresi logistik dalam penelitian ini adalah sebagai berikut:

$$
\begin{aligned}
& \operatorname{Ln} \frac{G C}{1-G C}=\alpha+\beta_{1} P Y O+\beta_{2} S I Z E+\beta_{3} C R+\beta_{4} R O A+\beta_{5} D T \\
& \text { Keterangan: } \\
& \quad: \quad \begin{array}{l}
\text { Opini Audit Going Concern } \\
\quad(1=\text { opini going concern dan } 0=\text { opini nongoing concern })
\end{array}
\end{aligned}
$$


Printed ISSN : $2406-7415$

Electronic ISSN : 2655 - 9919

DOI: http://dx.doi.org/10.35137/jabk.v8i2.537

Jurnal Akuntansi dan Bisnis Krisnadwipayana Volume 8 No. 2 (Mei - Agustus) 2021

$\begin{array}{lll}\alpha & : & \text { Konstanta } \\ \text { PYO } & : \text { Opini Audit Tahun Sebelumnya } \\ \text { SIZE } & : \text { Ukuran Perusahaan } \\ \text { CR } & : \text { Likuiditas } \\ \text { ROA } & : \text { Profitabilitas } \\ \text { DTA } & : \text { Solvabilitas } \\ \beta_{1-5}: & \text { Koefisien masing-masing variable } \\ \varepsilon & : \text { Error }\end{array}$

2. Uji Simultan (Omnibus)

Menurut Ghozali (2018), pengujian pengaruh secara simultan dapat dilihat pada tabel Omnibus Test of Model Coefficient yang digunakan untuk mengetahui pengaruh dari variableindependensecara simultan terhadap variable dependendengan dengan tingkat kepercayaan yang digunakan adalah $95 \%$ atau taraf signifikansi 5\% $(\alpha=0,05)$. Kriteria pengujian yang digunakan dalam penelitian ini adalah sebagai berikut:

a. Jika probabilitas signifikansi dari Model Coefficient pada Omnibus Test $>0,05$, maka hipotesis nol diterima yang berarti terdapat pengaruh signifikan antara variableindependensecara simultan terhadap variable dependen.

b. Jika probabilitas signifikansi dari Model Coefficient pada Omnibus Test $<0,05$, maka hipotesis nol ditolak yang berarti tidakterdapat pengaruh signifikan antara variableindependensecara simultan terhadap variable dependen.

\section{HASIL PENELITIAN DAN PEMBAHASAN}

Hasil

\section{Statistik Deskriptif}

Berdasarkan hasil uji statistik deskriptif diperoleh sebanyak 85 data observasi yang berasal dari perkalian antara periode penelitian (selama lima tahun dari tahun 2014 hingga tahun 2018) dengan jumlah perusahaan sampel (17 perusahaan). Dalam penelitian ini terdapat variableindependenyang terdiri dari opini audit tahun sebelumnya, ukuran perusahaan, likuiditas, profitabilitas, dan solvabilitas serta variable dependen, yaitu opini audit going concern. Untuk variabel ukuran perusahaan, likuiditas, profitabilitas, dan solvabilitas dapat diketahui nilai minimum, nilai maksimum, nilai rata-rata (mean), dan standar deviasi dari data dalam skala rasio, sedangkan data dalam skala nominal untuk variabel opini audit tahun sebelumnya dan opini audit going concern dapat dijelaskan dari frekuensi atau jumlahnya. Adapun hasil 
Printed ISSN : $2406-7415$

Electronic ISSN : 2655 - 9919

DOI: http://dx.doi.org/10.35137/jabk.v8i2.537

Jurnal Akuntansi dan Bisnis Krisnadwipayana Volume 8 No. 2 (Mei - Agustus) 2021

dari analisis statistik deskriptif adalah sebagai berikut:

Tabel 3

Uji Statistik Deskriptif

Descriptive Statistics

\begin{tabular}{|l|r|r|r|r|r|}
\hline & N & Minimum & Maximum & Mean & Std. Deviation \\
\hline SIZE & 85 & 25,72 & 32,02 & 29,5099 & 1,51390 \\
\hline CR & 85 &, 06 & 20,17 & 1,7634 & 2,88515 \\
\hline ROA & 85 &,- 72 &, 46 &,- 0362 &, 16982 \\
\hline DTA & 85 &, 04 & 1,99 &, 6661 &, 41113 \\
\hline $\begin{array}{l}\text { Valid N } \\
\text { (listwise) }\end{array}$ & 85 & \multicolumn{7}{|c|}{} \\
\hline
\end{tabular}

Sumber: Data diolah oleh penulis, 2020

Berdasarkan hasil perhitungan statistik deskriptif diketahui bahwa nilai minimum dari variabel ukuran perusahaan (SIZE) adalah 25,72, nilai maksimum 32,02, dan nilai standar deviasi 1,51390 . Nilai ratarata sebesar 29,5099 memiliki kecenderungan mendekati nilai maksimum yang menunjukkan bahwa sebagian besar sampel penelitian yang digunakan termasuk dalam kategori perusahaan berskala besar.Rasio likuiditas yang digunakan dalam penelitian ini adalah current ratio (CR). Hasil pengujian tabel 3 menunjukkan nilai nimimum 0,06 , nilai maksimum 20,17, serta nilai standar deviasi 2,88515. Nilai rata-rata likuiditas diperoleh sebesar 1,7634 yang menunjukkan bahwa kemampuan perusahaan sampel secara rata-rata dapat memenuhi kewajiban jangka pendek yang

dimiliki oleh perusahaan. Hasil analisis deskriptif terhadap profitabilitas (ROA) menunjukkan nilai minimum sebesar 0,72 , nilai maksimum sebesar 0,46 dengan rata-rata sebesar $-0,0362$ dan standar deviasi sebesar 0,16982. Hasil analisis tersebut menunjukkan bahwa rata-rata kemampuan perusahaan dalam menghasilkan laba sebesar $3.62 \%$.Berdasarkan hasil analisis statistik deskriptif diperoleh nilai nimimum terhadap variabel solvabilitas (DTA) sebesar 0,04 dan nilai maksimum sebesar 1,99. Nilai deviasi terhadap variabel solvabilitas diperoleh sebesar 0,41113 dengan nilai rata-rata sebesar 0,6661 yang menunjukkan bahwa sebesar $66,61 \%$ pendanaan perusahaan diperoleh dengan pinjaman dari kreditor.

\section{Tabel 4}

Statistik Frekuensi Variabel Opini Audit Tahun Sebelumnya Opini Audit Tahun Sebelumnya 
Printed ISSN : $2406-7415$

Electronic ISSN : 2655 - 9919

DOI: http://dx.doi.org/10.35137/jabk.v8i2.537

Jurnal Akuntansi dan Bisnis Krisnadwipayana Volume 8 No. 2 (Mei - Agustus) 2021

\begin{tabular}{|l|l|r|r|r|r|}
\hline \multicolumn{2}{|c|}{} & Frequency & Percent & \multicolumn{1}{|c|}{$\begin{array}{c}\text { Valid } \\
\text { Percent }\end{array}$} & $\begin{array}{c}\text { Cumulative } \\
\text { Percent }\end{array}$ \\
\hline \multirow{3}{*}{ Valid } & 0 & 48 & 56.5 & 56.5 & 56.5 \\
\cline { 2 - 6 } & 1 & 37 & 43.5 & 43.5 & 100.0 \\
\cline { 2 - 6 } & Total & 85 & 100.0 & 100.0 & \\
\hline
\end{tabular}

Sumber: Data diolah oleh penulis, 2020

Berdasarkan tabel 4 dapat diketahui bahwa selama periode penelitian tahun 20142018, jumlah perusahaan yang tidak memperoleh opini audit going concern pada tahun sebelumnya (kode 0) adalah sebesar $56,5 \%$ atau sebanyak 48

perusahaan dan jumlah perusahaan yang memperoleh opini audit going concern pada tahun sebelumnya (kode 1) adalah sebesar 43,5\% atau sebanyak 37 perusahaan.

Tabel 5

Statistik Frekuensi Variabel Opini Audit Going Concern

\begin{tabular}{|l|l|r|r|r|r|}
\hline \multicolumn{7}{|c|}{ Opini Audit Going Concern } \\
\hline \multirow{3}{*}{} & Frequency & Percent & $\begin{array}{c}\text { Valid } \\
\text { Percent }\end{array}$ & $\begin{array}{c}\text { Cumulative } \\
\text { Percent }\end{array}$ \\
\hline \multirow{3}{*}{ Valid } & 0 & 45 & 52.9 & 52.9 & 52.9 \\
\cline { 2 - 6 } & 1 & 40 & 47.1 & 47.1 & 100.0 \\
\cline { 2 - 6 } & Total & 85 & 100.0 & 100.0 & \\
\hline
\end{tabular}

Sumber: Data diolah oleh penulis, 2020

Berdasarkan tabel 5 dapat diketahui bahwa selama periode penelitian tahun 20142018, jumlah perusahaan yang tidak memperoleh opini audit going concern pada tahun berjalan (kode 0) adalah sebesar $52,9 \%$ atau sebanyak 45 perusahaan dan jumlah perusahaan yang memperoleh opini audit going concern pada tahun berjalan (kode 1) adalah sebesar $47,1 \%$ atau sebanyak 40 perusahaan. Hasil ini memberikan informasi bahwa selama tahun 2014-2018, perusahaan sektor pertambangan di Bursa Efek Indonesia lebih banyak yang tidak

mendapatkan opini audit going concern daripada yang menerima opini audit going concern.

\section{Analisis Regresi Logistik}

\section{Menilai Keseluruhan Model}

Pengujian dilakukan dengan membandingkan antara nilai $-2 \log L$ awal (Block 0) dengan nilai -2LogL akhir (Block 1). Model dapat diterima apabila terjadi penurunan nilai $-2 \log L$ awal ke 2LogLakhir. Berikut adalah hasil output SPSS terhadap uji overall model fit

\section{Tabel 6}

Uji Keseluruhan Model Block 0

\section{Iteration History ${ }^{\text {a,b,c }}$}

\section{4}

Copyright (c) 2021 Hayuningtyas Pramesti Dewi, SE., Ak., M.Ak., CA., Rodiyatan Mardiyah. 
Printed ISSN : $2406-7415$

Electronic ISSN : 2655 - 9919

DOI: http://dx.doi.org/10.35137/jabk.v8i2.537

Jurnal Akuntansi dan Bisnis Krisnadwipayana Volume 8 No. 2 (Mei - Agustus) 2021

\begin{tabular}{|l|l|r|r|}
\hline \multicolumn{2}{|c|}{ Iteration } & \multirow{2}{*}{-2 Log likelihood } & \multicolumn{2}{c|}{ Coefficients } \\
\cline { 4 - 4 } Step 0 & 1 & 117,541 & \multicolumn{2}{|c|}{ Constant } \\
\cline { 2 - 4 } & 2 & 117,541 &,- 118 \\
\hline
\end{tabular}

a. Constant is included in the model.

b. Initial -2 Log Likelihood: 117.541

c. Estimation terminated at iteration number 2 because parameter

estimates changed by less than .001 .

Sumber: Data diolah oleh penulis, 2020

Tabel 7

Uji Keseluruhan Model Block 1

\begin{tabular}{|c|c|c|c|c|c|c|c|c|}
\hline \multicolumn{9}{|c|}{ Iteration History $^{\mathrm{a}, \mathrm{b}, \mathrm{c}, \mathrm{d}}$} \\
\hline \multirow{2}{*}{\multicolumn{2}{|c|}{ Iteration }} & \multirow{2}{*}{$\begin{array}{c}-2 \text { Log } \\
\text { likelihood }\end{array}$} & \multicolumn{6}{|c|}{ Coefficients } \\
\hline & & & Constant & $\mathrm{PYO}$ & SIZE & $\mathrm{CR}$ & ROA & DTA \\
\hline \multirow[t]{8}{*}{ Step 1} & 1 & 51,434 &, 428 & 2,717 &,- 079 &, 032 & $-2,533$ & ,682 \\
\hline & 2 & 41,097 &,- 098 & 3,538 &,- 107 &, 083 & $-5,432$ & 1,908 \\
\hline & 3 & 37,819 & 1,206 & 3,872 &,- 203 &, 152 & $-7,221$ & 3,808 \\
\hline & 4 & 36,899 & 4,776 & 3,947 &,- 375 & 215 & $-7,512$ & 5,930 \\
\hline & 5 & 36,790 & 7,156 & 3,997 &,- 479 & 239 & $-7,521$ & 6,939 \\
\hline & 6 & 36,788 & 7,581 & 4,007 &,- 497 & 241 & $-7,528$ & 7,085 \\
\hline & 7 & 36,788 & 7,591 & 4,008 &,- 497 & 242 & $-7,528$ & 7,088 \\
\hline & 8 & 36,788 & 7,591 & 4,008 &,- 497 & ,242 & $-7,528$ & 7,088 \\
\hline
\end{tabular}

a. Method: Enter

b. Constant is included in the model.

c. Initial -2 Log Likelihood: 117.541

d. Estimation terminated at iteration number 8 because parameter estimates changed by less than .001 .

Sumber: Data diolah oleh penulis, 2020

Pada tabel 6 menunjukkan hasil uji overall model fit terhadap Block 0 diperoleh nilai $-2 \log L$ sebesar 117,541 . Berdasarkan tabel 11 hasil pada Block 1 diperoleh nilai $-2 \log L$ sebesar 36,788. Jika hasil -2LogLBlock 0 dibandingkan dengan hasil -2LogLBlock 1, maka terjadi penurunan sebesar 80,753. Nilai penurunan tersebut menunjukkan bahwa model yang dihipotesiskan fit dengan data dan penggunaan konstanta dengan lima variabel bebas mampu menjelaskan pengaruhnya terhadap pengeluaran opini audit going concern. Untuk membuktikan penurunan nilai $-2 \log L$ menunjukkan bentuk modelyang fit dapat dilihat dari nilai Chi-square pada hasil analisis Omnibuss Test of Model Coefficient.

\section{Hasil Uji Kelayakan Model Regresi}

Kelayakan model regresi dalam penelitian ini dinilai dengan menggunakan 
Printed ISSN : $2406-7415$

Electronic ISSN : 2655 - 9919

DOI: http://dx.doi.org/10.35137/jabk.v8i2.537

Jurnal Akuntansi dan Bisnis Krisnadwipayana Volume 8 No. 2 (Mei - Agustus) 2021

Hosmer and Lemeshow's Goodness of Fit Test, yang merupakan model untuk menguji bahwa tidak adanya perbedaan antara model dengan data sehingga model dapat dikatakan fit (data sesuai dengan model).

Tabel 8

Uji Kelayakan Model Regresi

\begin{tabular}{|c|c|c|c|}
\hline \multicolumn{4}{|c|}{ Hosmer and Lemeshow Test } \\
\hline Step & Chi-square & $\mathrm{df}$ & Sig. \\
\hline 1 & 4,638 & 7 & ,704 \\
\hline
\end{tabular}

Sumber: Data diolah oleh penulis, 2020

Berdasarkan tabel di atas menunjukkan hasil uji kelayakan model regresi diperoleh nilai Chi-square hitung sebesar 4,638 dengan probabilitas signifikansi 0,704 . Karena nilai signifikansi 0,704 lebih besar dari 0,05, maka dapat disimpulkan bahwa

model regresi dalam penelitian ini dapat diterima dan dinyatakan mampu memprediksi nilai observasinya.

\section{Uji Koefisien Determinasi (Nagelkarke} R Square)

Tabel 9

Uji Koefisien Determinasi

\begin{tabular}{|l|c|c|cr|}
\hline \multicolumn{4}{|c|}{ Model Summary } \\
\hline \multirow{2}{*}{ Step } & $\begin{array}{c}-2 \text { Log } \\
\text { likelihood }\end{array}$ & $\begin{array}{c}\text { Cox \& Snell R } \\
\text { Square }\end{array}$ & $\begin{array}{c}\text { Nagelkerke R } \\
\text { Square }\end{array}$ \\
\hline 1 & $36,788^{\mathrm{a}}$ &, 613 & &, 819 \\
\hline
\end{tabular}

a. Estimation terminated at iteration number 8 because parameter estimates changed by less than .001 .

Sumber: Data diolah oleh penulis, 2020

Berdasarkan tabel di atas, diperoleh nilai koefisien determinasi dari Nagelkerke $R$ Square sebesar 0,819. Hasil tersebut menunjukkan kemampuan variable independen(opini audit tahun sebelumnya, ukuran perusahaan, likuiditas, profitabilitas, dan solvabilitas) dalam menjelaskan variable dependen(opini audit going concern) pada perusahaan pertambangan yang terdaftar di Bursa Efek

Indonesia sebesar 81,90\%. Sedangkan sisanya sebesar $18,10 \%$ dijelaskan oleh variabel-variabel lain di luar model penelitian.

\section{Tabel Klasifikasi}

Hasil tabel klasifikasi ditampilkan sebagai berikut:

\section{Tabel 10}


Printed ISSN : $2406-7415$

Electronic ISSN : 2655 - 9919

DOI: http://dx.doi.org/10.35137/jabk.v8i2.537

Jurnal Akuntansi dan Bisnis Krisnadwipayana Volume 8 No. 2 (Mei - Agustus) 2021

Uji Tabel Klasifikasi

\begin{tabular}{|l|l|l|r|r|r|}
\hline \multicolumn{6}{|c|}{ Classification Table $^{\mathbf{a}}$} \\
\cline { 3 - 6 } & \multirow{2}{*}{ Observed } & \multicolumn{3}{|c|}{ Predicted } \\
\cline { 3 - 6 } & \multicolumn{2}{|c|}{$\begin{array}{c}\text { GC } \\
\text { Correct }\end{array}$} \\
\cline { 3 - 6 } Step 1 & GC & 0 & 0 & 1 & 93,3 \\
\cline { 3 - 6 } & & 1 & 42 & 3 & 92,5 \\
\cline { 3 - 6 } & \multicolumn{2}{|c|}{ Overall Percentage } & & & 92,9 \\
\hline
\end{tabular}

a. The cut value is .500

Sumber: Data diolah oleh penulis, 2020

Berdasarkan tabel di atas menunjukkan bahwa kekuatan untuk memprediksi probabilitas perusahaan menerima opini audit going concern adalah sebesar 92,5\%. Hasil tersebut menunjukkan sebanyak 37 perusahaan dari total 40 perusahaan diprediksi akan menerima opini audit going concern.Sedangkan kekuatan untuk memprediksi probabilitas perusahaan menerima opini audit nongoing concern adalah sebesar 93,3\%. Hal ini menunjukkan bahwa terdapat 42 dari 45 perusahaan diprediksi akan menerima opini audit nongoing concern. Secara keseluruhan, kekuatan prediksi dari

sampel yang diuji adalah sebesar 92,9\% yang nilainya lebih dari 50\%, sehingga dapat disimpulkan bahwa predictive validity model cukup baik.

\section{Pengujian Hipotesis Penelitian}

\section{Uji Parsial (Uji Wald)}

Pengujian pengaruh secara parsial dapat dilihat pada tabel variabel in the equation yang digunakan untuk mengetahui pengaruh dari masing-masing variable independenterhadap variable dependendengan tingkat signifikansi sebesar $5 \%(\alpha=0,05)$.

Tabel 11

Uji Signifikansi Model Secara Parsial

\begin{tabular}{|l|l|r|r|r|r|r|r|}
\hline \multicolumn{7}{|c|}{ Variables in the Equation } \\
\hline \multirow{2}{*}{$\begin{array}{l}\text { Step } \\
1^{\text {a }}\end{array}$} & B & \multicolumn{1}{c|}{ S.E. } & Wald & df & \multicolumn{1}{c|}{ Sig. } & \multicolumn{1}{c|}{$\operatorname{Exp(B)}$} \\
\cline { 2 - 8 } & SIZE & 4,008 &, 952 & 17,709 & 1 &, 000 & 55,012 \\
\cline { 2 - 8 } & CR &,- 497 &, 503 &, 976 & 1 &, 323 &, 608 \\
\cline { 2 - 8 } & ROA & $-7,528$ & 4,051 & 3,454 & 1 &, 063 &, 001 \\
\cline { 2 - 9 } & DTA & 7,088 & 3,898 & 3,306 & 1 &, 069 & 1197,933 \\
\cline { 2 - 9 } & Constant & 7,591 & 13,130 &, 334 & 1 &, 563 & 1979,502 \\
\hline
\end{tabular}

a. Variable(s) entered on step 1: PYO, SIZE, CR, ROA, DTA. 
Printed ISSN : $2406-7415$

Electronic ISSN : 2655 - 9919

DOI: http://dx.doi.org/10.35137/jabk.v8i2.537

Jurnal Akuntansi dan Bisnis Krisnadwipayana Volume 8 No. 2 (Mei - Agustus) 2021

Sumber: Data diolah oleh penulis, 2020

Model regresi logistik yang diperoleh adalah sebagai berikut:

$$
\ln \frac{G C}{1-G C}=7,591+4,008 P Y O-0,497 S I Z E+0,242 C R-7,528 R O A+7,088 D T A+\varepsilon
$$

Variabel konstan model regresi logistik memiliki koefisien positif sebesar 7,591 yang menunjukkan jika variable independendianggap nol, maka opini audit going concern sebesar 7,591.Koefisien regresi terhadap opini audit tahun sebelumnya (PYO) diperoleh nilai sebesar 4,008 yang menunjukkan bahwa jika perusahaan memperoleh opini audit going concern pada tahun sebelumnya, maka probabilitas perusahaan mendapatkan opini audit going concern meningkat sebesar 4,008 satuan dengan asumsi nilai koefisien variabel lain tetap. Variabel opini audit tahun sebelumnya diperoleh nilai wald sebesar 17,709 dengan tingkat signifikansi sebesar 0,000 yang nilainya lebih kecil dari 0,05. Hal ini menunjukkan bahwa hipotesis pertama diterima atau terdapat pengaruh signifikan variabel opini audit tahun sebelumnya terhadap opini audit going concern.Koefisien regresi terhadap ukuran perusahaan (SIZE) diperoleh nilai sebesar $-0,497$ yang menunjukkan bahwa jika terdapat kenaikan 1 satuan pada ukuran perusahaan, maka probabilitas perusahaan akan menerima opini audit going concern menurun sebesar 0,497 satuan dengan asumsi nilai koefisien variabel lain tetap. Variabel ukuran perusahaan diperoleh nilai wald sebesar 0,976 dengan tingkat signifikansi sebesar 0,323 yang nilainya lebih besar dari 0,05. Hal ini menunjukkan bahwa hipotesis kedua tidak diterima atau tidak terdapat pengaruh signifikan variabel ukuran perusahaan terhadap opini audit going concern.Koefisien regresi terhadap likuiditas (CR) diperoleh nilai sebesar 0,242 yang menunjukkan bahwa jika terdapat kenaikan 1 satuan pada likuiditas, maka probabilitas perusahaan akan menerima opini audit going concern meningkat sebesar 0,242 satuan dengan asumsi nilai koefisien variabel lain tetap. Variabel likuiditas diperoleh nilai waldsebesar 1,389 dengan tingkat signifikansi sebesar 0,239 yang nilainya lebih besar dari 0,05. Hal ini menunjukkan bahwa hipotesis ketiga tidak diterima atau tidak terdapat pengaruh signifikan variabel likuiditas terhadap opini audit going concern.Koefisien regresi terhadap profitabilitas (ROA) diperoleh nilai sebesar -7,528 yang menunjukkan bahwa jika terdapat kenaikan 1 satuan pada profitabilitas, maka probabilitas perusahaan akan menerima opini audit going concern menurun sebesar 7,528 satuan dengan asumsi nilai koefisien variabel lain tetap. Variabel profitabilitas diperoleh nilai wald sebesar 3,454 dengan tingkat signifikansi sebesar 0,063 yang nilainya lebih besar dari 0,05 . Hal ini 
menunjukkan bahwa hipotesis keempat tidak diterima atau tidak terdapat pengaruh signifikan variabel profitabilitas terhadap opini audit going concern.Koefisien regresi terhadap solvabilitas (DTA) diperoleh nilai sebesar 7,088 yang menunjukkan bahwa jika terdapat kenaikan 1 satuan pada solvabilitas, maka probabilitas perusahaan akan menerima opini audit going concern meningkat sebesar 7,088 satuan dengan asumsi nilai koefisien variabel lain tetap.Variabel solvabilitas diperoleh nilai wald sebesar 3,306 dengan tingkat signifikansi sebesar 0,069 yang nilainya lebih besar dari 0,05 . Hal ini menunjukkan bahwa hipotesis kelima tidak diterima atau tidak terdapat pengaruh signifikan variabel solvabilitas terhadap opini audit going concern.

\section{Uji Simultan (Omnibus)}

Pengujian ini dilakukan untuk menguji apakah model regresi logistik terhadap variabel opini audit tahun sebelumnya, ukuran perusahaan, likuiditas, profitabilitas, dan solvabilitas secara simultan berpengaruh terhadap variabel opini audit going concern. Analisis dilakukan dengan membandingkan nilai Sig. pada tabel Omibus Test of Model Coefficients terhadap tingkat signifikansi sebesar 0,05. Hasil Omibus Test of Model Coefficients disajikan dalam tabel sebagai berikut.

Tabel 12

Uji Signifikansi Model Secara Simultan

\begin{tabular}{|c|c|c|c|c|}
\hline \multicolumn{5}{|c|}{ Omnibus Tests of Model Coefficients } \\
\hline & & Chi-square & df & Sig. \\
\hline \multirow[t]{3}{*}{ Step 1} & Step & 80,753 & 5 & ,000 \\
\hline & Block & 80,753 & 5 &, 000 \\
\hline & Model & 80,753 & 5 & ,000 \\
\hline
\end{tabular}

Sumber: Data diolah oleh penulis, 2020

Berdasarkan table diatas dapat diketahui bahwa diperoleh nilai Chi-square hitung sebesar 80,753 dengan df 5. Hasil uji signifikansi model secara simultan menunjukkan nilai signifikansi sebesar 0,000 karena nilai signifikansi lebih kecil dari 0,05, maka dapat disimpulkan bahwa terdapat pengaruh signifikan secara simultan variabel opini audit tahun sebelumnya, ukuran perusahaan, likuiditas, profitabilitas, dan solvabilitas terhadap opini audit going concern. 
DOI: http://dx.doi.org/10.35137/jabk.v8i2.537

\section{KESIMPULAN DAN SARAN}

1. Opini audit tahun sebelumnya berpengaruh terhadap penerimaan opini audit going concern. Hal ini

menunjukkan bahwa dalam penerbitan opini audit going concern, auditor akan mempertimbangkan opini audit dari tahun sebelumnya.

2. Ukuran perusahaan tidak berpengaruh terhadap penerimaan opini audit going concern. Hal ini menunjukkan bahwa besar kecilnya perusahaan sama-sama memiliki peluang untuk memperoleh opini audit going concern.

3. Likuiditas tidak berpengaruh terhadap penerimaan opini auditgoing concern. Hal ini menunjukkan bahwa pertimbangan dalam pemberian opini audit going concern cenderung dilihat dari kondisi keuangan secara keseluruhan, sedangkan current ratio tidak dapat dijadikan sebagai tolak ukur dalam menentukan kelangsungan usaha perusahaan.

4. Profitabilitas tidak berpengaruh terhadap penerimaan opini audit going concern. Hal ini menunjukkan bahwa kemampuan perusahaan dalam menghasilkan laba tidak dapat dijadikan acuan bagi auditor dalam memberikan opini audit going concern akan tetapi melihat kondisi keuangan secara keseluruhan.

5. Solvabilitas tidak berpengaruh terhadap penerimaan opini auditgoing concern. Hal ini menunjukkan bahwa pertimbangan pemberian opini audit
Printed ISSN : $2406-7415$

Electronic ISSN : 2655 - 9919

Jurnal Akuntansi dan Bisnis Krisnadwipayana Volume 8 No. 2 (Mei - Agustus) 2021

\section{Kesimpulan}

going concern tidak dapat dilihat berdasarkan kemampuan perusahaan dalam melunasi keseluruhan utangnya saja melainkan kondisi keuangan secara keseluruhan.

6. Opini audit tahun sebelumnya, ukuran perusahaan, likuiditas, profitabilitas, dan solvabilitas secara simultan berpengaruh terhadap penerimaan opini audit going concern. Hal ini menunjukkan bahwa pertimbangan pemberian opini audit going concern ditinjau dari banyak sisi seperti opini sebelumnya, ukuran perusahaan baik kecil maupun besar, dan kinerja keuangan yang saling berkaitan satu sama lain sehingga memperkuat seorang auditor memberikan opini audit going concernnya.

\section{SARAN}

Opini audit going concern menjadi sangat penting karena menunjukkan keberlangsungan usaha suatu perusahaan. Karena itu manajemen perusahaan sebaiknya dapat mengenali tanda-tanda kebangkrutan usaha dengan menganalisis laporan keuangannya sehingga dapat mengambil keputusan dan kebijakan agar terhindar dari penerimaan opini audit going concern.Adapun untuk investor maupun calon investor atau pemberi pinjaman yang ingin melakukan investasi dan memberikan pinjaman sebaiknya cermat dan teliti dalam memilih perusahaan serta tidak berinvestasi pada perusahaan yang memperoleh opini audit 
going concern dalam laporan keuangan yang telah diaudit.

\section{DAFTAR PUSTAKA}

Agoes, S. (2016). Auditing Petunjuk Praktis Pemeriksaan Akuntan oleh Akuntan Publik. Jakarta : Salemba Empat

Anita, W. F. (2017). Analisis FaktorFaktor yang Mempengaruhi Opini Audit Going Concern pada Perusahaan Manufaktur yang Terdaftar di Bursa Efek Indonesia, Jurnal Riset Keuangan dan Akuntansi, 3(1), pp. 87-108

Boynton, W. C., Johnson, R. N. \& Kell, W. G. (2015). Modern Auditing. Jakarta : Erlangga

Ghozali, I. (2018). Aplikasi Analisis Multivariate dengan Program IBM SPSS 25. Semarang : Universitas Diponegoro

Halim, A. (2015). Dasar-Dasar Audit Laporan Keuangan. Yogyakarta : UPP STIM YKPN

Harahap, S. S. (2015). Analisis Kritis atas Laporan Keuangan. Jakarta : PT Raja Grafindo Persaja

Hartono, J. (2017). Teori Portofolio dan Analisis Investasi. Yogyakarta : BPFE.

Haryanto, Y. A. \& Sudarno.(2019). Pengaruh Profitabilitas, Solvabilitas, Likuiditas, dan Rasio Pasar terhadap Opini Audit Going Concern pada Perusahaan Manufaktur di Bursa Efek Indonesia, Diponegoro Journal of Accounting, 8(4), pp. 1-13
Institut, A. P. I. (2011). Standar Profesional Akuntan Publik. Jakarta : Salemba Empat

Kasmir.(2017). Analisis Laporan Keuangan. Jakarta : PT Rajagrafindo Persada

Keown, A. J. (2018). Manajemen Keuangan: Prinsip-Prinsip dan Aplikasi. Jakarta : Gramedia Pustaka Utama

Kontan. (2019). Tertekan Penurunan Harga Kinerja Emiten Batubara Melorot di Kuartal III 2019. [online]. (diupdate 02 November 2019). https://amp.kontan.co.id/news/tertek an-penurunan-harga-kinerja-emitenbatubara-melorot-di-kuartal-iii-2019 Krissindiastuti, M. \& Rasmini, N. K. (2016). Faktor-faktor yang mempengaruhi opini audit going concern, E-Jurnal Akuntansi Universitas Udayana, 14(1), pp. 451-481

Lie, C., Wardani, R. P. \& Pikir, T. W. (2016). Pengaruh Likuiditas, Solvabilitas, Profitabilitas, dan Rencana Manajemen terhadap Opini Audit Going Concern (Studi Empiris Perusahaan Manufaktur di BEI), Berkala Akuntansi dan Keuangan Indonesia, 1(2), pp. 84-105

Minerva, L., Sumeisey, V. S., Stefani, S., Wijaya, S., \& Lim, C. A. (2020). Pengaruh Kualitas Audit, Debt Ratio, Ukuran Perusahaan dan Audit Lag terhadap Opini Audit Going 
Printed ISSN : $2406-7415$

Electronic ISSN : 2655 - 9919

DOI: http://dx.doi.org/10.35137/jabk.v8i2.537

Jurnal Akuntansi dan Bisnis Krisnadwipayana Volume 8 No. 2 (Mei - Agustus) 2021

Concern, Owner (Riset \& Jurnal

Akuntansi), 4(1), pp. 254-266

Nugroho, L., Nurrohmah, S. \& Anasta, L.

(2018). Faktor-faktor yang

mempengaruhi opini audit going concern, Jurnal Sikap, 2(2), pp. 96111

Sudana, I. M. (2015). Manajemen Keuangan Perusahaan Teori dan Praktik. Jakarta : Erlangga

Sugiono, A \& Untung, E. (2016). Analisa Laporan Keuangan. Jakarta : PT Grasindo

Tuanakotta, T. M. (2015). Audit Kontemporer. Jakarta : Salemba Empat

Undang-Undang Nomor 20 Tahun 2008. Tentang Usaha Mikro, Kecil, dan Menengah. Jakarta: Kementerian Sekretariat Negara. 
Printed ISSN : $2406-7415$

Electronic ISSN : 2655 - 9919

DOI: http://dx.doi.org/10.35137/jabk.v8i2.537

Jurnal Akuntansi dan Bisnis Krisnadwipayana

Volume 8 No. 2 (Mei - Agustus) 2021

Copyright (c) 2021 Hayuningtyas Pramesti Dewi, SE., Ak., M.Ak., CA. , Rodiyatan Mardiyah.

\section{(C) 100}

This work is licensed under a Creative Commons Attribution-NonCommercial-ShareAlike 4.0 International License 